\title{
排水横主管合流による排水立て管システムの排水能力影響に関する基礎的研究 \\ AN INVESTIGATION BASIC STUDY ON INFLUENCE OF FLOW CAPACITY FOR COMBINED DRAINAGE LOAD IN THE DRAINAGE SYSTEM
}

\author{
本鄉智大*, 大塚雅之**, 武田 仁*** \\ Norihiro HONGO, Masaynki OTSUKA and Hitoshi TAKEDA
}

\begin{abstract}
The purpose of this study is to grasp the influence of combined drainage load in house drain in to drainage stack system, and flow capacity of house drain. And the object of further study will be to establish and purpose new testing evaluation method which it is consider the influence of combined drainage load. This paper discusses the following points, (1) The way to provide combined drainage load in house drain, (2) Conditions of Pressure variation by combined drainage load in drainage system and an evaluation method thereof and (3) Understanding of the flow capacity of house drain in a drainage system by combined drainage load.
\end{abstract}

Keywords : Drainage system, Flow capacity, House drain, Pressure variation, Combined drainage load 排水システム, 排水能力, 排水横主管, 圧力変動, 合流排水負荷

\section{1.はじめに}

建物内排水システムの設計では、各住居からの排水時に生じる管内 圧力によって、衛生器具のトラップの封水を破らないことが原則であ る。そのための排水能力陚験法として、1999 年に “SHASE-S218 集 合住宅の排水立て管システムの排水能力試験法”（以下、 SHASE-S218）が策定された。同試験法では、最も基本となる排水 立て管と長さ $5[\mathrm{~m}]$ の排水横主管（以下、一次排水横主管）から構成 される排水立て管システムの排水能力を把握することを目的として いる。しかし、実際の建物内の排水システムでは、例えば図 1 のよう に多数の排水立て管システムが排水横主管部に接続された複雑な配 管形態となっているのでSHASE-S218では他系統の排水システムか らの排水影響を把握できない。高層集合住宅の排水システムを例にあ げれば、既往文献 1のように排水立て管径 $100[\mathrm{~mm}]$ 程度の複数の 排水立て管システムが全長 $50[\mathrm{~m}]$ を超える管径 $150[\mathrm{~mm}]$ 程度の大 口径の排水横主管（以下、二次排水横主管）にヘッダー状に接続され ている場合が多く見られる。複数の排水立て管システムを流下する排 水が二次排水横主管内で朝夕のピーク排水時間に合流し重なること や、その際に洗剤排水泡の滞留によって、排水管内が閉塞する恐れが あることも指摘されている。それらの影響によって排水管内が閉塞さ れることにより、排水管内の空気が圧縮され、過度の正圧が生じ、排 水立て管の下層階に接続された衛生器具のトラップの封水が跳ね出 した事故例 2）も報告されている。

しかし、設計技術を体系化した SHASE-S206 給排水設備規準・

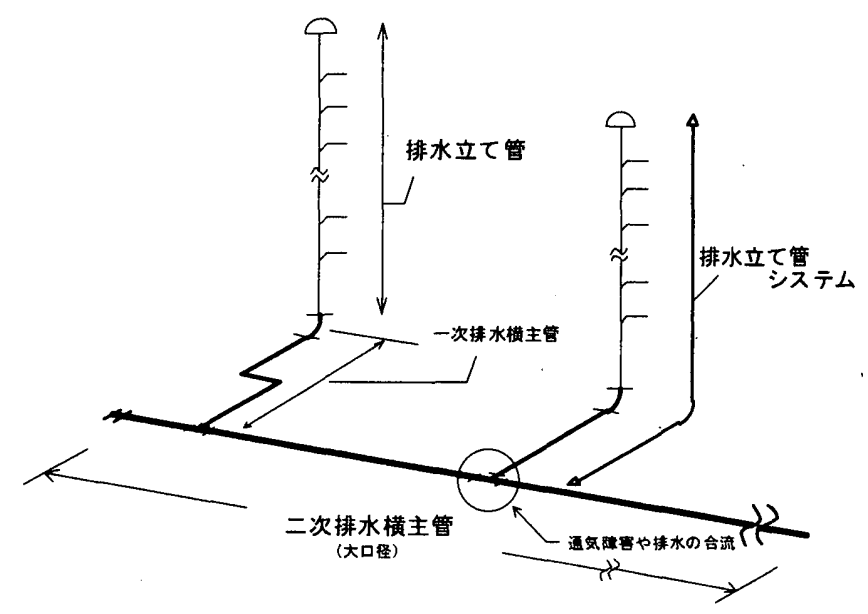

図 1 集合住宅排水システムの概略図

同解説（以下、SHASE-S206）では、排水システムの設計法におい て、排水立て管システムと排水横主管の許容流量を別々に設定してい ることから、排水横主管内での合流排水などの通気の阻害要因による 排水能力の低下やその回避策が十分解説されていないのが現状で、実 務的にも大きな課題点といえる。本来は、排水立て管と排水横主管の 影響を考虑して排水システムの許容流量值を定めるべきである。今後 更に SHASE-S218 を建物全体の排水システムの影響をも含めた試験 法に拡張する場合、SHASE-S218 で定めた排水立て管シスデムの排 水能力を保持することを基淮に、排水横主管内での合流影響を考慮し

\footnotetext{
* 山形県立産業技術短期大学校建築環境システム科 講師・工修

** 関東学院大学工学部建築設備工学科 教授 $\cdot$ 工博

*** 東京理科大学理工学部建築学科 教授. 工博
}

Lect., Dept. of Architecture Environment System Engineering, Yamagata College of Industry and Technology, M. Eng.

Prof., Dept. of Architectural Environmental Engineering, Kanto-Gakuin Univ., Dr. Eng.

Prof., Dept. of Architecture, Faculty of Science and Technology, Science Univ., of Tokyo, Dr. Eng. 
た排水能力試験法（排水横主管合流試験法）を提案することも必要で ある。

以上の背景から本研究では、複数の排水立て管システムからの合流 排水負荷が二次排水横主管内に生ずる場合の排水立て管システムの 排水能力に及ぼす影響を定量的に把握することと共に、二次排水横主

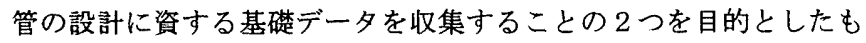
のである。それらに関する検討結果から将来的には、二次排水横主管 での合流影響を考慮した排水立て管システムの排水能力試験法を立 案することも視野にいれた実験研究である。そのために本報では二次 排水横主管上での合流負荷方法の差異、排水能力評価方法について基 本的な実験を行った。更にその実験結果を現行の SHASE-S206に規 定される排水横主管の許容流量值と比較し、低减率についても検討す る。

\section{2 .実験方法}

本報では、（1）排水立て管システムの排水能力試験、（2）合流負 荷方法検討実験、（3）合流負荷実験の3つの実験を順次実施した。 その主旨と概要を以下に述べる。

\section{1 排水立て管システムの排水能力試䭆}

東京理科大学理工学部キャンパス内の地上 10 階建 (高さ約 $30[\mathrm{~m}]$ ) の高層排水負荷実験装置に供試排水立て管システムを設置し、既往の SHASE-S218 で排水能力を把握する。図 2 に示す供試排水立て管シ ステムは JS-DT 継手を使用した管径 $100[\mathrm{~mm}]$ の伸頂通気方式の 排水システムである。

図 2 の供試排水立て管に図 3 の 2 種頑の形態を有する管径 125 [mm]の一次排水横主管を接続する。これらは SHASE-S218 に準 拠した管長 $6[\mathrm{~m}]$ ストレート配管（以下、ストレート）と、 SHASE-S206 の規定による排水立て管基部から $3[\mathrm{~m}]$ の距離をおい て水平曲がりを設けた配管（以下、 $3[\mathrm{~m}]$ 曲がり）の 2 種類の一次 排水横主管を有するシステムで、排水能力を確認する。

この結果を以降の検討で、供試排水立て管システムの排水能力とし た。

\section{2 合流負倚方法検討実臨}

2.1 で確認した排水能力に対し、複数の排水立て管システムからの 排水が、二次排水横主管内で合流した場合の影響を評価する方法を検 討する。そのために用いる合流装置と合流方法を提案し、排水能力へ の影響を確認する。合流影響は、図 2 の供試排水立て管システムを 2 系統（以下、供試排水立て管システム（I）、（II））用意し、それら を管径 $150[\mathrm{~mm}]$ の二次排水横主管に TL 継手 $(125[\mathrm{~mm}] \times 150$ [mm]）を用いて接続した図 4 の合流負荷実験装置を用いて確認す る。一次排水横主管と二次排水横主管の接続距離は、前述の SHASE-S206 に準拠し、排水立て管基部より $3[\mathrm{~m}]$ の位置とした。

また、二次排水横主管の最上流側の $\mathrm{G}$ 点より別途、排水負荷を与え ることができる負荷装置も併設し（以下、供試排水立て管システム (III))、二次排水横主管の下流側末端には排水桝を設け、その端部は 大気開放とし、水没等による通気を阻害する要因はないものとした。 合流方法は、図 5 に示寸とおり供試排水立て管システム（I）に対 して上流側、下流側の各排水立て管システムを想定して合流排水を行 う。その際、供試排水立て管システム (I ) を基準排水立て管システ ム（I）とする。また、二次排水横主管内で基準排水立て管からの排 水流れを阻害する負荷を上流負荷、下流負荷とした。

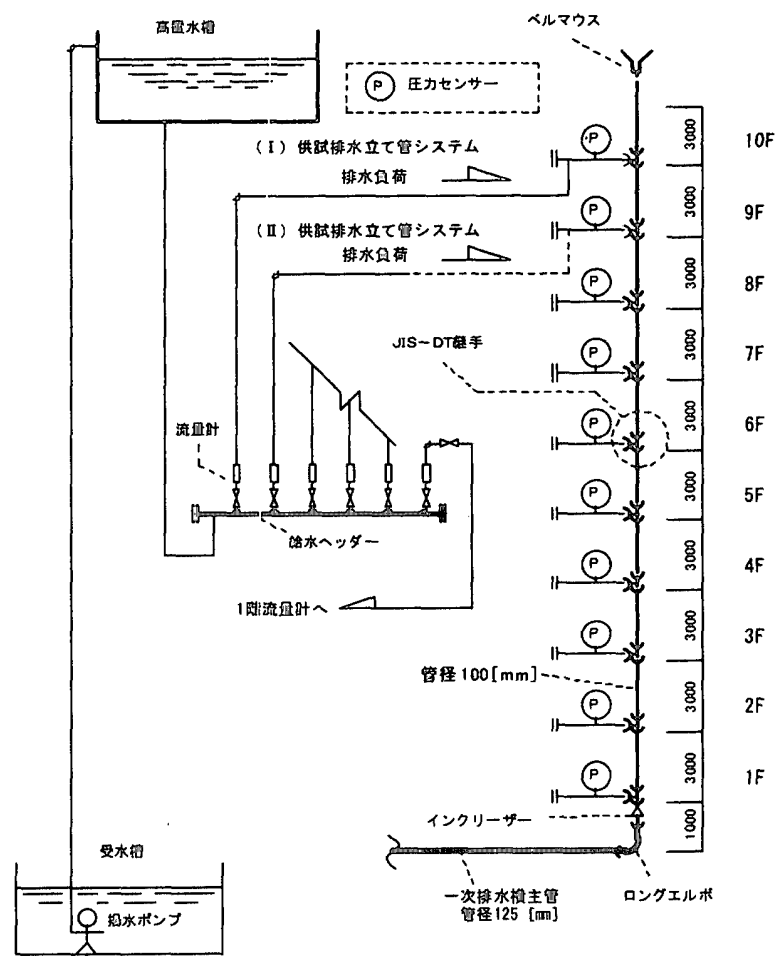

図 2 供:試排水立て管システム系統図

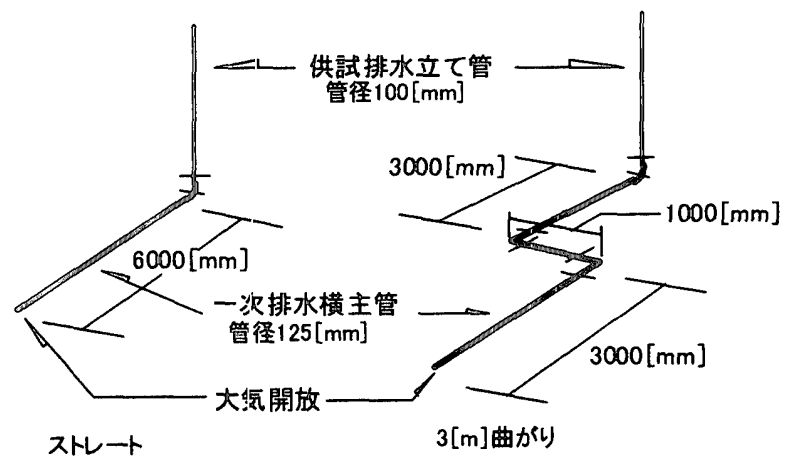

図 3 一次排水横主管形態

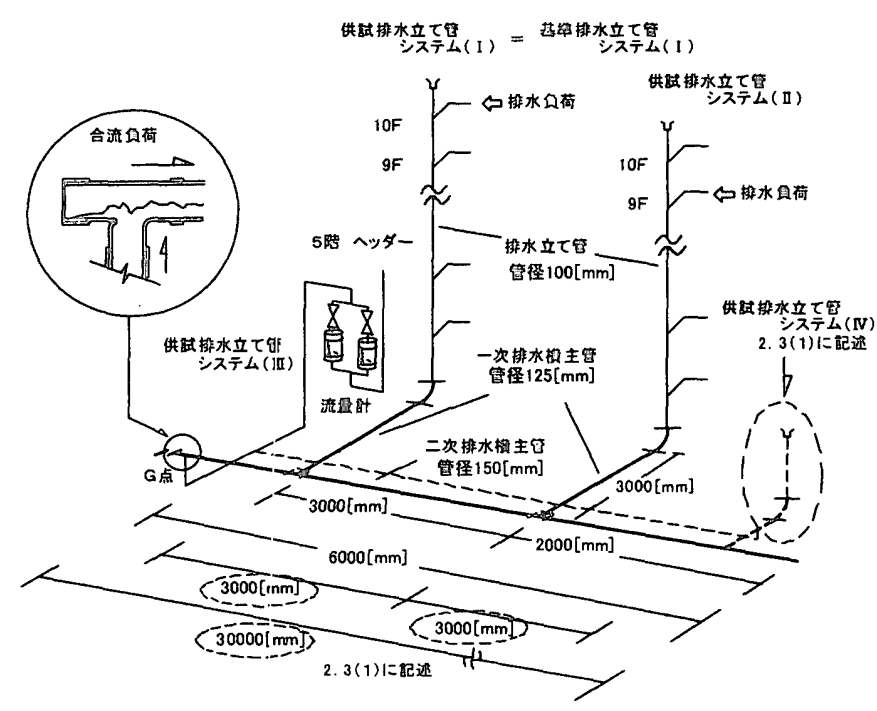

図 4 合流負荷実験装置 
上流負荷は、基準排水立て管システム（I）の排水に対して、上流 側排水システム系統からの排水合流を想定した合流である (図 4 の G 点、供試排水立て管システム（III）から排水負荷を与える)。下流負 荷は、基準排水立て管システム（I）の排水に対して、下流側にある 供試排水立て管システム（II）より排水負荷を与える。

\section{3 合流負荷実験}

2.2 で決定した合流方法を用いて、二次排水横主管の許容流量値を 示すとともに、その評価方法についても検討した。

\section{（1）合流試験装置}

合流試験装置は、図 4 の供試排水立て管システム（II）の $3[\mathrm{~m}]$ 下流側に図 5 のように下流負荷として排水負荷を与えられる排水立 て管システム（IV）を設置した。この排水立て管は排水立て管の配管 長をオリフィス板の通気抵抗で代用させた代用排水立て管システム （以下、供試排水立て管システム（IV)）であり、装置の施工条件の 制約から実際の排水システムとは異なる。（I）、（II）、（IV）の各排 水立て管システムを管径 $150[\mathrm{~mm}]$ の全長約 $30[\mathrm{~m}]$ に延長させた 二次排水横主管に接続した。

図 4 の供試排水立て管システム（I）、（II）、(IV) の 3 系統の排水 立て管システムから二次排水横主管へ排水負荷を与えることができ、 排水横主管端部は水没等による通気を阻害する要因はない。

（2）合流負荷の与え方

供試排水立て管システム（I）を 2.2 と同様に基準排水立て管シス テム（I ）とする。基準排水立て管システム（I）に2.1で設定した 排水能力を与えた状態で、供試排水立て管システム（II）（IV）より $1.5[\mathrm{~L} / \mathrm{s}] 、 2.0[\mathrm{~L} / \mathrm{s}]$ と排水負荷流量を増加させ、共に供試排水立て 管システムの排水能力まで与える。

\section{4 测定項目・方法}

測定項目はSHASE-S218 に準拠し、供試排水立て管各階の排水横 枝管の管内圧力（10 点）と下層階 1 階〜3 階に設置した洗濯機パン 用トラップ（脚断面積比：1.08）の封水損失を測定した。また、洗濯 機パン用の逆わんトラップ（以下、供試トラップ）の破封状況を目視 で確認した。図 6 に測定システム系統図を示す。

\section{3 .結果及び考察}

\section{1 供試排水立て管システムの排水能力試験}

図 7 は、負荷最上階となる 10 階より排水負荷 $1.0 \sim 2.5[\mathrm{~L} / \mathrm{s}]$ を与 えた時の供試排水立て管システムに生じた管内圧力のシステム最大 值 Ps max（以下、Ps max)、最小値 Ps min（以下、Ps min）と排 水負荷流量 QL関保を整理したものである。これより、負圧側に着 目し、排水横主管形態がストレートと $3 \mathrm{~m}$ 曲がりを同一排水負荷流量 QL で比較すると、最大で $50[\mathrm{~Pa}]$ 程度の差異が生じている。

正圧側では、 $3 \mathrm{~m}$ 曲がりの排水負荷流量 $\mathrm{Q}_{\mathrm{L}}=2.5[\mathrm{~L} / \mathrm{s}]$ の時のシス テム最大值 Ps max が+120 [Pa] 程度となるが、過度の正圧とはな ってはいない。両システムとも 2.5 [L/s] の時に SHASE-S218 の判 定基準 \pm 400 [Pa］を上回る結果となった。また、SHASE-S206に 淮拠し、一次排水横主管を変形した場合では、基準となるストレート 配管の排水能力は同等であり懸念される正圧は発生せず、この条件下 では一次排水横主管形態の影響は受けない。全長 $6[\mathrm{~m}]$ の一次排水横 主管を有する排水立て管システムの排水能力は、負圧の判定基準一 400[Pa]のみで規定されため合流による正圧影響を確認する試験が別 途必要になるものと考える。

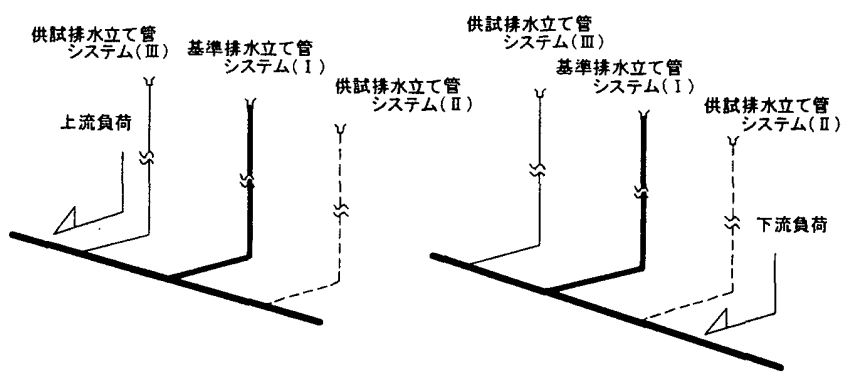

上流負荷
下流負荷



封水損失 3個所

目盛り

図 6 测定システム系統図



図 7 供試排水立て管システムの排水能力

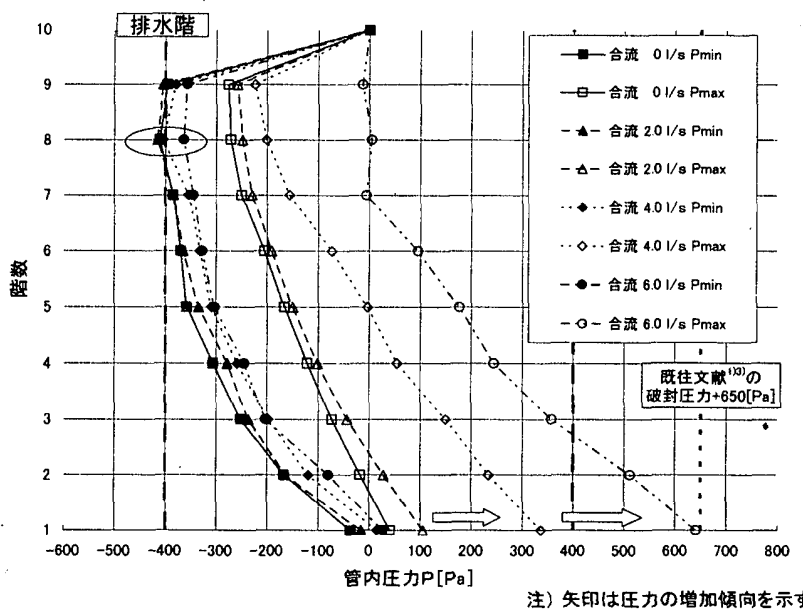

図 8 合流排水時の管内圧力分布（上流負荷） 




图9（1） IF 聂大正圧(合流なし)

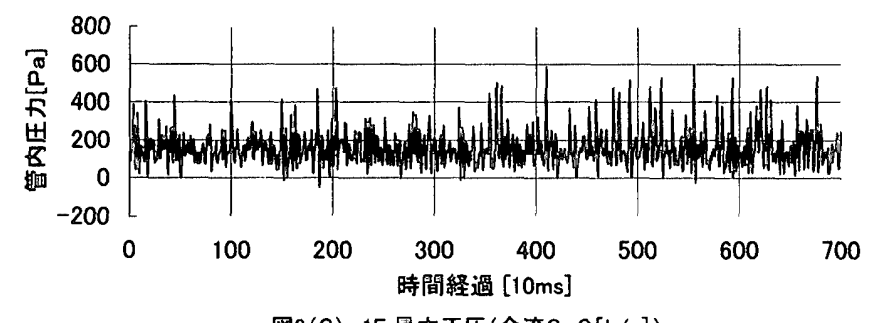

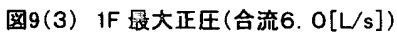

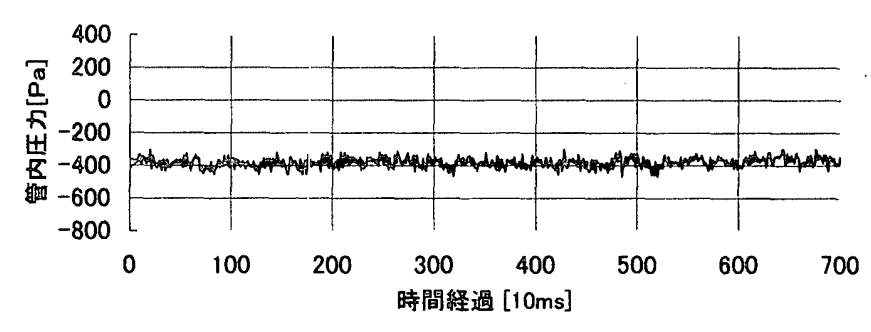



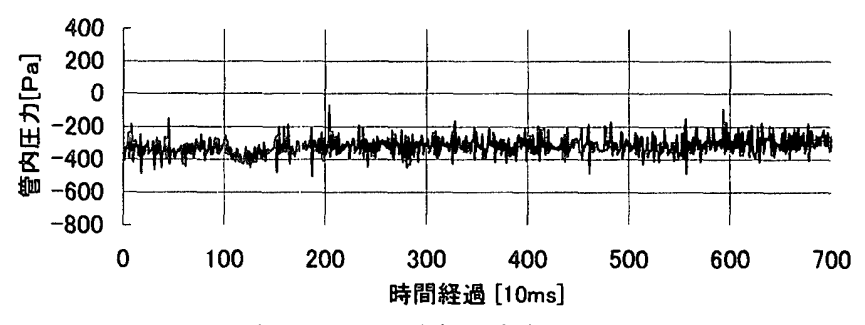

图9４４）8F 摱大負压(合流6. $O[L / s]$ )

図 9 管内压力

以降では、ここで確認された供試排水立て管システムの排水能力 $2.25[\mathrm{~L} / \mathrm{s}]$ を基淮とし、それに対する他系統からの合流影響の評価 を行った。

\section{2 合流負侍方法検討実聒}

（1）合流負荷の基本特性

基準排水立て管システム ( I )への合流影響を検討した一例として、 図 8 k基淮排水立て管システム ( I ) の各階管内圧力の最大值 P max、 最小值 Pmin の管内圧力分布を示す。図 8 は基準排水立て管システム （I）に前述の排水能力 $2.25[\mathrm{~L} / \mathrm{s}]$ を与えたまま、供試排水立て管 システム (III) から合流排水負荷を $6.0[\mathrm{~L} / \mathrm{s}](2.0[\mathrm{~L} / \mathrm{s}]$ 刻み) ま で合流させた基準排水立て管システム（I）の管内圧力分布を示した ものである。基淮排水立て管システム（I）の上層階となる 8～9 階 で発生するPs min は、合流排水負荷が $0[\mathrm{~L} / \mathrm{s}]$ の時に-411 [Pa] であったが、6.0 [L/s $]$ の時に-364 [Pa] となり、僅かに負圧が緩 和している。基準排水立て管システム（I）の下層階の 1 階で発生し たPs max は、合流排水負荷が $0[\mathrm{~L} / \mathrm{s}]$ の時に+45 [Pa]、2.0[L/s ] の時に+105 [Pa]、4.0[L/s] の時に+336 [Pa $)$ と合流する負荷流量 が増加するほど Ps $\max$ は大きくなり、6.0 [L/s $]$ の時には+640 [Pa $]$ に達し判定基準值士400 [Pa] を大きく上回り、既往文献 13)で言われ る、逆わんトラップのトラップ封水の破封圧カ+650 800 [Pa] 付近 に達する。

（2）管内圧力の特徴

合流排水による基準排水立て管システム（I）の管内圧力に着目し、 一例として 8 階と 1 階の管内圧力を図 9 に示寸。基淮排水立て管シ ステ台（I）に対して、合流排水負荷のない場合と、合流排水負荷の ある場合（合流 $6.0 \mathrm{~L} / \mathrm{s}$ ）の管内圧力である。これより、排水立て管の 8 階では、合流排水負荷の有無かかわらずに、多少の変動差はあるが 稳やかな管内圧力を示し安定している。排水立て管の 1 階では、既往 文献 4) が指摘しているように合流排水負荷によって周期性を持った 過度の正圧値が発生しており、8 階と 1 階の排水横枝管では、管内圧 力の特徵が異なる。
図 10 に図 9 の管内压力の測定值を 70 秒間でサンプリングした場 合の度数分布を示した。8 階の管内圧力の平均値（以下、Pave）は、 合流排水負荷のある場合でー345[Pa]、ない場合でー380[Pa]となり、 その差が 35[Pa]程度と僅かである。既往文献 5)でも検討されるように 各々の合流排水負荷での標準偏差 (以下、 $\sigma$ ) を求めると、 $\pm 59[\mathrm{~Pa}]$ 、 $\pm 31[\mathrm{~Pa}]$ となり、その慈 $28[\mathrm{~Pa}]$ 程度と僅かであった。
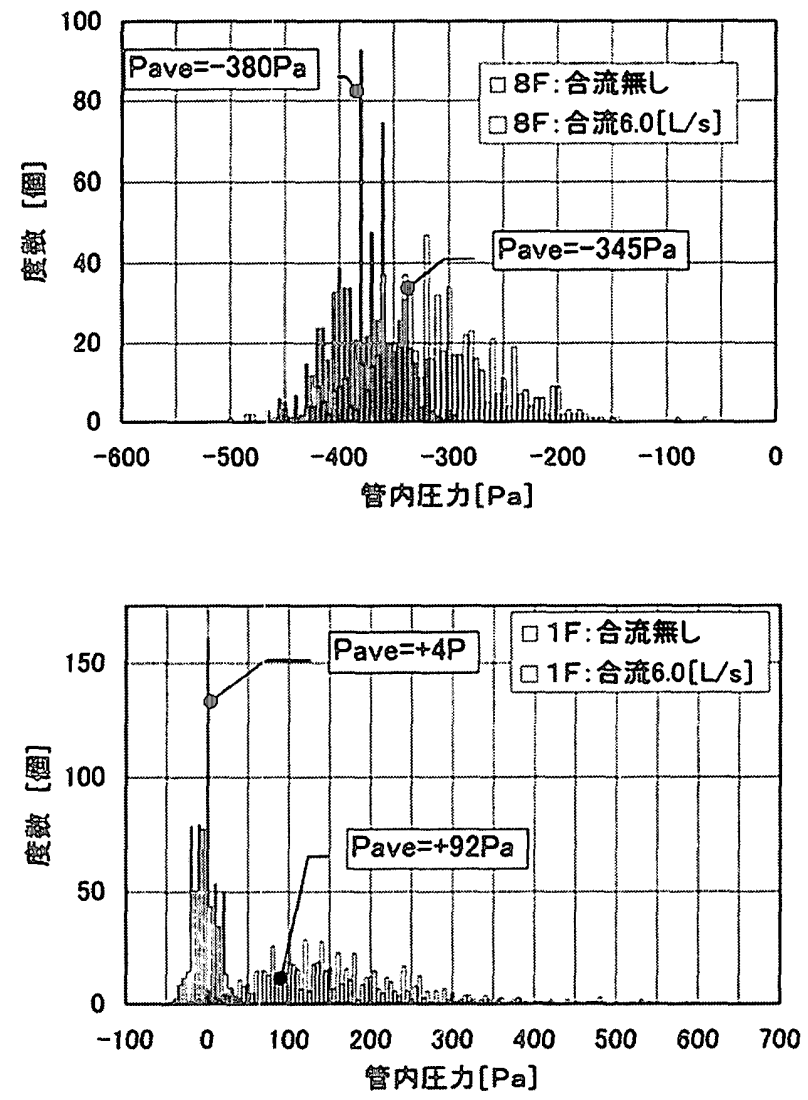

図 10 管内圧力の度数分布（8階と 1 階） 


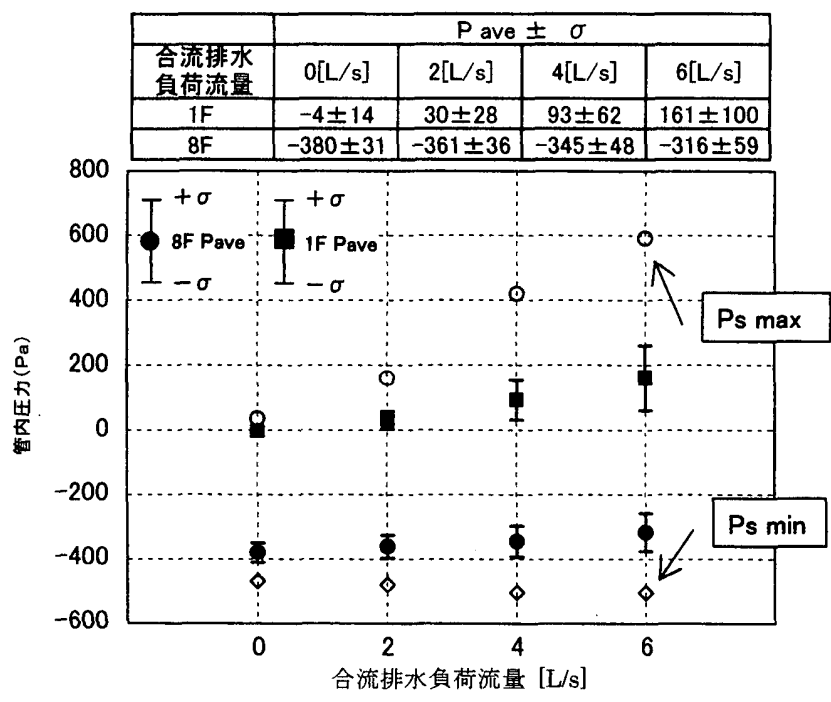

図 11 合流排水負荷流量 (上流負荷) と

Pave $\pm \sigma 、 P s \max 、$ Ps min の関倸

また、下層 1 階の場合では、Pave は合流排水負荷のある場合に+ $92[\mathrm{~Pa}]$ 、ない場合に+4[Pa]となり、その差 $88[\mathrm{~Pa}]$ と正圧側に移動す る。 $\sigma$ も $\pm 100[\mathrm{~Pa}] 、 \pm 14[\mathrm{~Pa}]$ となり、 $\sigma$ 差も $86[\mathrm{~Pa}]$ 程度合流がある 場合の方が大きくなり、圧力に大きなバラツキが生じていることがわ かる。

図 11 に合流排水負荷流量と Pave $\pm \sigma$ 、Ps max、Ps min の関倸を 示す。8階では合流排水負荷の増加によって多少は下層階の正圧発生 への影響はあるが、Pave からの変動は小さく安定した圧力值であり、 合流排水負荷が上層階の負圧に及ぼす影響は少ないと考えられる。し かし、1 階では合流排水負荷によって Pave からの変動值が增加する 傾向を示し、正圧域と負圧域では変動の状況が異なる。また、合流排 水負荷 $6.0[\mathrm{~L} / \mathrm{s}]$ の場合の Ps max は+592[Pa]に達し、合流のない 場合のPs max $+36[\mathrm{~Pa}]$ に比べ、下層階の圧力値の変動は大きく、過 度の圧力値が発生している。

（3）合流負荷方法検討実験

（1）では基準排水立て管システムの排水能力を、（2）ではそれに 対する二次排水横主管上での上流負荷の影響を検討した。その結果に 対し、下流負荷の影響を検討したのが図 12 である。同図は合計負荷 流量 Q と Ps max の関係を示したものであり、正圧側の判定基準+ $400[\mathrm{~Pa}]$ で判定すれば、上流負荷の $\mathrm{Q}$ が約 $7.0[\mathrm{~L} / \mathrm{s}]$ 以上、下流 負荷の $Q$ が約 4.8 [ L/s $]$ 以上で判定基準値を超える。

その時の合計負荷流量 $\mathrm{Q}$ を排水横主管の許容流量値として、 SHASE-S206 に規定される排水横主管の許容流量値 $8.3[\mathrm{~L} / \mathrm{s}]$ （管径 $150[\mathrm{~mm}] 、$ 勾配 1/100）と比較すると、+400 [Pa] 以内で判定し た場合は、SHASE-S206 の許容流量值を下回る。また、洗濯機パン 用トラップの破封限界となる正圧側の判定条件が既往文献 1)3)の+650 [Pa] 程度と示されており、それを判定条件とすると、上流負荷の $\mathrm{Q}$ が約 $8.6[\mathrm{~L} / \mathrm{s}]$ 、下流負荷の Q が約 $5.5[\mathrm{~L} / \mathrm{s}]$ となり、上流負荷に よる許容流量値に対し、下流負荷は $64 \%$ となる。下流負荷において はいずれの判定条件の場合も SHASE-S206 の許容流量値を下回った。

同一の合計負荷流量 Q で比較しても、下流負荷を与えた場合が基 準排水立て管システム（I）に対して、厳しい合流排水負荷方法条件 となることがわかった。

よって、合流負荷実験では基準排水立て管システム（I）への影響
を、下流負荷を用いて検討する。

\section{3 合流負荷実臨}

（1）下層階最大值 $\mathrm{P} \max$ とトラップ破封の有無

図 13 に基準排水立て管システム（I）に対し、下流側での合流排 水負荷を与えた時の合計負荷流量 $\mathrm{Q}$ と 1 3 階の $\mathrm{P} \max$ をプロット し近似曲線で示した。これより正圧側の判定 $+400[\mathrm{~Pa}$ で流、正圧の 排水横主管から及ぶ高さで判断すると $\mathrm{Q}$ は 1 階（一次排水横主管よ り高さ $1.0[\mathrm{~m}]$ 位置) で約 $5.8[\mathrm{~L} / \mathrm{s}] 、 2$ 階（高さ $4.0[\mathrm{~m}]$ 位㯰）で 約 $6.2[\mathrm{~L} / \mathrm{s}] 、 3$ 階 (高さ $7.0[\mathrm{~m}]$ 位置) で約 $6.4[\mathrm{~L} / \mathrm{s}]$ が許容值となる。

また、正圧側の+650[Pa]判定では、同様に Q は 1 階で $6.2[\mathrm{~L} / \mathrm{s}] 、 2$ 階で $6.4[\mathrm{~L} / \mathrm{s}] 、 3$ 階で $6.6[\mathrm{~L} / \mathrm{s}]$ が許容值と見なせる。いずれの判定条 件でもSHASE-S206 に規定される排水横主管許容流量值 8.3[L/s]を 下回る結果となった。また、下層階（1～3 階）に供試トラップを設 置し合流排水負荷を与え、その時の管内圧力と供試トラップの破封の 有無も確認した。同図には 1 3 階の Pmax を記号でプロットし、破 封のない場合の記号を白抜きして示した。これより、圧力値は正圧側 の判定基準 $+650[\mathrm{~Pa}]$ 以上で供試トラップの破封が生ずる頻度が高か った。また $\mathrm{Q}=6.6[\mathrm{~L} / \mathrm{s}]$ の時には、2階においては+400[Pa]以下でも 破封しており、これはその時の 1 階での破封影響が 2 階に達したもの と考えられる。

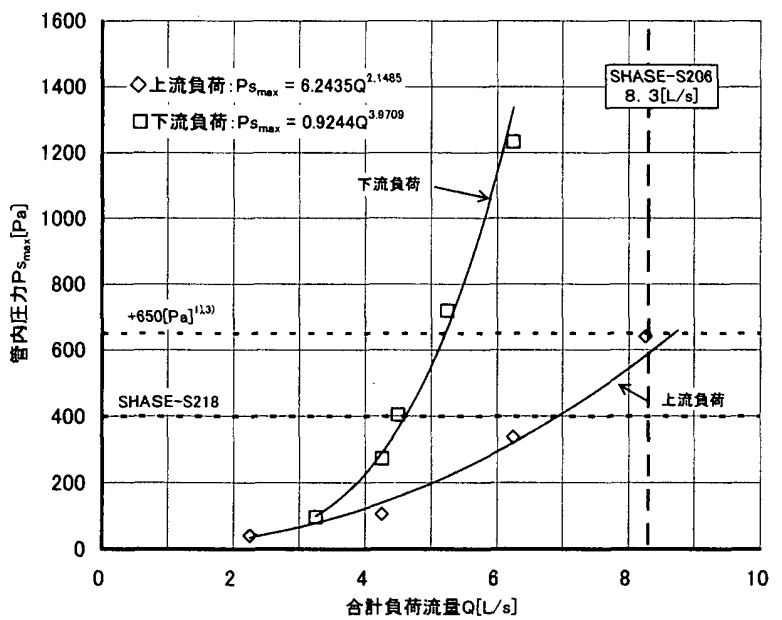

図 12 合計負荷流量 QとPs max の関倸

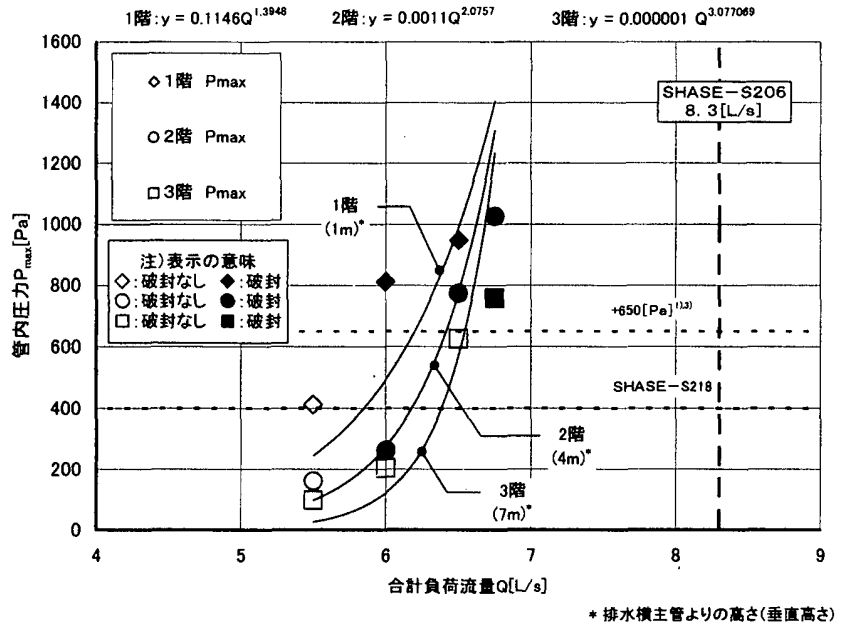

図 13 合計負荷流量 QとP max の関係 
表 1 にSHASE-S206 の伸頂通気方式の排水横主管許容流量を基淮 值とし、それに対する $1 \sim 3$ 階の圧力值で判断して求めた許容流量値 (本試験許容流量値) の比を低减率として示した。その結果、試験条 件は限定されるが SHASE-S206 の許容流量値の 0.7 0.8 程度と見込 め、マニングの式を用いた開水路非圧送流となる緩やかな排水流れと 本実験のように速い排水流れによる差があることが指摘でき、実状の 排水の流れに合った数值へ許容流量值を修正して行くことが今後の 課題といえる。

（2）トラップの固有振動数と合計負荷流量 Q

図 14 は、一例として 2 階 $\mathrm{Pmax}$ の $\mathrm{Q}=6.0 \sim 6.75[\mathrm{~L} / \mathrm{s}]$ の場合のパワ 一スペクトルを示したものであり、（1）の結果を同図より考察してみ る。同図には、既往文献 6)よりトラップ封水の固有振動数注1)を求め、 示した。これより、Q の増加によって、供試トラップの固有振動数 $(2.2[\mathrm{~Hz}])$ 付近に卓越したパワーが発生する傾向にあり、そのパワ 一の值も合計負荷流量の増加と伴に増えて $\mathrm{Q}=6.75[\mathrm{~L} / \mathrm{s}]$ 付近ではト ラップの破封の危険性が高まる傾向に有ることが推察できる。しかし、 瞬時正圧とパワースペクトルの関係を性能評価の指標とするには、合 流排水影響のデータを蓄積し、検討を重ねる必要ある。

4.まとめ

本報では、排水横主管での合流特性を把握するために簡易試験装置 を製作し、合流排水負荷の与え方、結果評価方法について考察した。 その結果、供試排水立て管や装置上の制約はあるが、JIS 継手使用 の伸頂通気方式に限定した場合で、以下の知見を得た。

（1）SHASE-S218 で正圧值評価を行う場合に SHASE-S206 で規 定する排水横主管の曲がり位置基準（3[m]曲がり）では、排 水能力上は正圧の影響はなく正圧値の限界を試験するには、 別途、合流排水影響を確認できる試験を検討する必要がある。

（2）10 階規模の排水立て管システムに合流排水負荷を与えた場合 の管内圧力は、合流排水のない場合に比べ上層階の負圧発生域 では負圧変動に変化は少ないが、正圧発生域となる下層階では 正圧変動が大きくなる特徵がある。

（3）二次排水横主管内での合流排水負荷の与え方は、排水立て管 システムに対して、上流側と下流側の負荷が考えられるが、 本実験で採用したような下流側排水負荷を合流させた方法が 険討した内では峳しい合流排水負荷条件となる。

（4）正圧側の圧力判定を、既往文献 8)で指摘するように+400[Pa] を基準として行うとトラップの破封に対し安全性が高いが、 既往文献 1)3)でも指摘のあるように+650 [Pa] 程度で洗濯機 パン用の逆わんトラップが破封することが本実験を通じて確 認され、正圧側の判定基準の見直し検討が必要であることを 指摘した。

（5）排水立て管システムに合流排水負荷を与えた場合の排水横主 管 $150[\mathrm{~mm}] の$ 実質的な許容流量値は、限定された試験範囲内 ではあるが SHASE-S206 で規定された值の 70〜80\%程度に 低下する。

[注]

注 1）既往文献 6)の次式によりトラップの固有㩔動数 $\mathrm{f}[\mathrm{Hz}]$ を求めた。 $f=1 / 2 \pi \sqrt{g\left(A_{1}+A_{2}\right) / N}$

f : 固有振動数 $(\mathrm{Hz}) \mathrm{g}$ :重力加速度 $\left(\mathrm{cm} / \mathrm{s}^{2}\right)$

$A_{1}:$ 流入脚断面積 $\left(\mathrm{cm}^{2}\right)$
表 1 排水粠主管の許容流量値 ${ }^{*)}$ と低滅率

\begin{tabular}{|c|c|c|c|c|c|c|c|c|}
\hline & \multirow{3}{*}{$\begin{array}{c}\text { SHASE-S206 } \\
\text { 非水樌主管 } 150[\mathrm{~mm} \\
\text { 句配 } 1 / 100\end{array}$} & \multirow{3}{*}{ 単位 } & \multicolumn{6}{|c|}{ 判定基準 } \\
\hline & & & \multicolumn{3}{|c|}{$+400[\mathrm{~Pa}]$} & \multicolumn{3}{|c|}{$+650[\mathrm{~Pa}]^{1,3)}$} \\
\hline & & & 1嘴 & 2階 & 3階 & 1階 & 2階 & 3階 \\
\hline \multirow[t]{2}{*}{ 伸頂通氮方式 } & \multirow{2}{*}{$8.3[\mathrm{~L} / \mathrm{s}]$} & {$[\mathrm{L} / \mathrm{s}]$} & 5.8 & 6.2 & 6.4 & 6.2 & 6.4 & 6.6 \\
\hline & & 低減率 & 0.70 & 0.75 & 0.77 & 0.75 & 0.77 & 0.80 \\
\hline
\end{tabular}

*) 本圾験篹囲内の許容流最値を使用

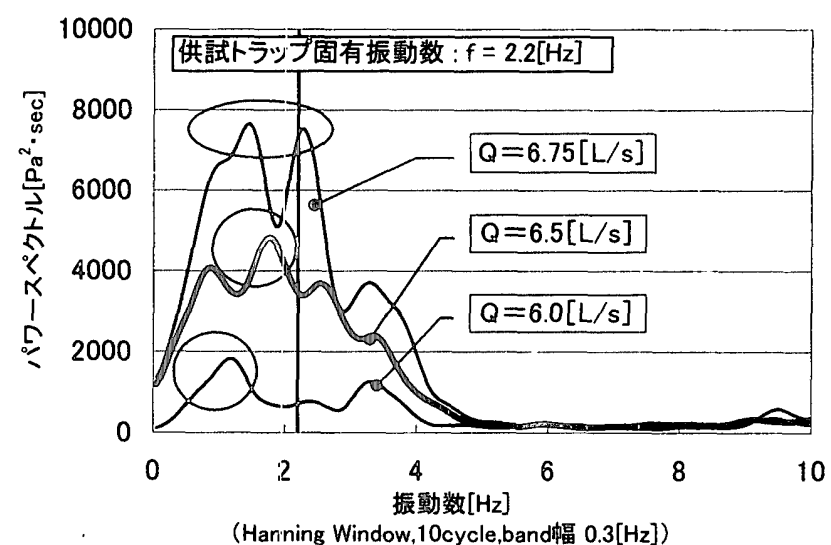

図 14 トラップの固有振動数とパワースペクトル

\begin{abstract}
$\mathrm{A}_{2}$ : 流出脚断面積 $\left(\mathrm{cm}^{2} \mathrm{I}^{2}\right)$
$\mathrm{V}$ ：封水全容稓 $\left(\mathrm{cm}^{3}\right.$;
\end{abstract}

[参考文献]

1）大塚雅之 他:集合住宅排水システムの排水負荷推定法に関する調查研究（その। 9 階建て高層住宅での排水负荷流量把握），日本建築学会計画系睮文集 第 536 号, pp. $63 \sim 70,2000.10$

2）安孫子義彦 他：「集合住宅の排水システム」21世紀に伝える日本建築画像体系,早 稲田大学理工学研究所, 1990

3）正久裕之 他:トラップの性能評佂法に関する研究その 9 トラップの許容压力に 関する分布, 日本建築学会大会学術講演梗概集 D-1,pp.579 580,2000.9

4）大塚雅之 他:排水システムの性能試験と理論計算体系のための基磷的研究（その

7 ）,空気調和・衛生工学会学術講演会講演論文集,pp.201 204,1988.9

5）空気調和・衛生工学会シンポジウム 単管式排水システムのあり方を考える,空気謂 和・衛生工学会排水通気性能小委員会,pp. $36,1996.3$

6）岩間 誠 他:トラップの性能評価法に関する研究 その 6 各種トラップの基本動 性能（2），日本建築学会大会学術講演梗概集 D·1,pp.557〜 558, 1999.9 7) 正久裕之 他:トラップの性能評価法に関寸る研究その 5 各種トラップの基本動特 性, 日本建築学会大会学術鿁演梗概集 D-1,pp.531 532, 1998.9

8）張月 他:トラップの性能試験法に関する研究（その1）正庄時の封水損失特性,空 気调和・衛生工学会学術講演会講演論文集,pp.1081 1084, 2002.9

9）大崎順彦:新・地震動のスペクトル解析入門,鹿島出版会 1994

10）空気調和・衛生工学会:SHASE-S206- 2000 給排水設備規準・同解説,2003

11）空気調和・衛生工学会:SHASE-S218.1999 集合住宅の排水システムの)排水能力試験 法,2003

[本論文に関連した口答発表]

12）本郷智大,大塚雅之 他:集合住宅排水システムの排水横主管合流試験法に関する 研究（その1合流負荷による排水横主管の基本特性）,日本建築学会学術講演梗 概集 D-1,pp.551 552, 1999.9 
13）本郷智大,大塚雅之 他:集合住宅排水システムの排水横主管合流試験法に関する 研究（その 2 合流負荷の基本影響実験）,空気調和・衛生工学会学術講演会諈演 論文集,pp.1065 1068,1999.9

14）本郷智大，大塚雅之 他:集合住宅排水システムの排水横主管合流試験法に関する 研究 (その 3 合流試験の負荷方法と評価法の検討)，空気調和・衛生工学会学術 講演会講演論文集, pp.1101 1104,2000.8

15) Hongo Norihiro et al:An Investigation Study on Testing Methods of Combined Drainage Load for Drainage System in Apartment Houses,CIB-W62,2001.9

(2003年 7 月 10 日原稿受理, 2004年 1 月22日採用決定) 